\title{
Kajian Dampak Sengketa Tanah Terhadap Hak Atas Pendidikan dari Perspektif Hukum Progresif
}

\author{
Arief Rachman Hakim¹, Joko Setiyono², Dananggana Satriatama3
}

1Program Studi Magister Ilmu Hukum Universitas Diponegoro,

E-mail: arief.hakim0893@gmail.com

2Fakultas Hukum Universitas Diponegoro, E-mail: jokosetiyono61@yahoo.com

2Program Studi Ilmu Hukum Universitas Negeri Surabaya, E-mail: danangsatria13@gmail.com

\begin{tabular}{l}
\hline Info Artikel \\
\hline Masuk: 31 Januari 2019 \\
Diterima: 7 Agustus 2019 \\
Terbit: 30 September 2019 \\
Keywords: \\
Education; Blockade; Human \\
Rights; Progressive Law \\
\\
Kata kunci: \\
Pendidikan; Penyegelan; Hak \\
Asasi; Hukum Progresif \\
Do.24843/JMHU.2019.v08.i03. \\
Arief Rachman Hakim, E-mail: \\
arief.hakim0893@gmail.com \\
\end{tabular}

\begin{abstract}
Education as part of constitutional rights frequently disturbed by land-rights dispute where there's a school building up to it. That land-rights dispute often deprived citizen rights which is a student because often ended in unilateral sealing action by claimant parties. This problem isn't only land-rights dispute or messy administration of land-rights in Indonesia, but always repeated and deprived the constitutional rights to gain an education. The purpose of this research is to obtain a theoretic solution over a school-land-rights dispute, where that's multidimensional conflict in which can't be solved only with the legalformal approach. Method of research in this writing is normative legal research where examine the legal problem, specifically the urgency of harmonization of legal-norm in existed positive-law so that law is consistent with highest legal-norm, which complies with constitution obligation. Progressive law theory used in this research to assert that law isn't only normative problems only, but the utilitarian side of the law for humanity itself. Results of this research show that the Gov's isn't ready to harmonizing the law to protect constitutional education rights itself because they rarely inventoried legal-education problem around. Furthermore, Gov's should prepare fully legal protection to protect education process in which constitutional rights, moreover, the integrity of law to determine the compensation to be given to specific parties must be proportional and adequate, both in the legal process or after so that kind of sealing couldn't happen again.
\end{abstract}

\begin{tabular}{l}
\hline Abstrak \\
\hline Pendidikan yang merupakan bagian dari hak konstitusional \\
masih sering terganggu oleh sengketa hak atas tanah di mana \\
berdiri bangunan sekolah di atasnya. Sengketa hak atas tanah \\
tersebut sering kali merenggut hak warga negara yakni peserta \\
didik karena sering berujung pada penyegelan sepihak oleh pihak \\
yang merasa memiliki hak. Problematika ini tidak sekedar \\
persoalan sengketa tanah atau carut marutnya administrasi \\
tanah di Indonesia, namun berulang dan merenggut hak \\
konstitusional warga negara untuk memperoleh pendidikan. \\
Tujuan penulisan ini adalah untuk mendapatkan solusi teoritik \\
terhadap problem sengketa tanah atas sekolah, di mana \\
merupakan konflik multi-dimensi yang tidak dapat selesai hanya \\
dengan cara legal formal semata. Metode penelitian yang
\end{tabular}




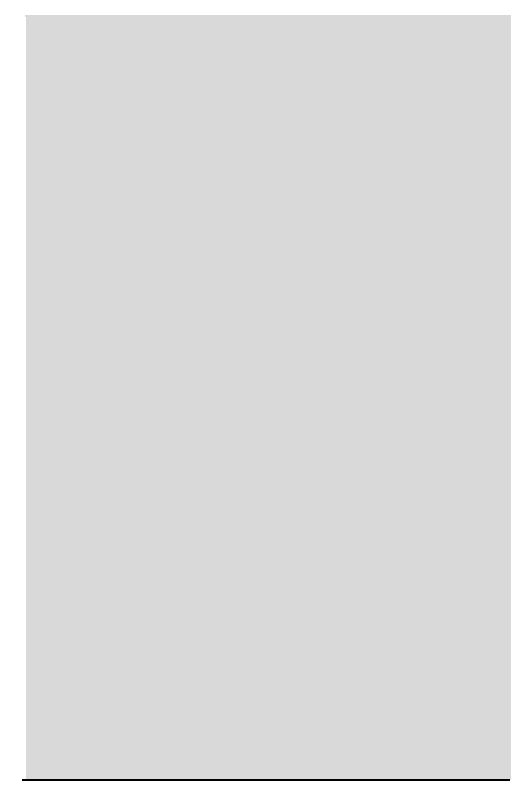

digunakan yakni yuridis normatif di mana membahas problematika yuridis, yakni perlunya harmonisasi norma hukum yang ada agar sesuai dengan norma hukum tertinggi yaitu kewajiban konstitusional. Penggunaan teori hukum progresif yang menegaskan hukum bukan hanya persoalan normatif tapi juga kemanfaatan hukum untuk manusia. Hasil penelitian menunjukkan bahwa pemerintah tidak siap dalam harmonisasi hukum untuk menjaga hak konstitusional memperoleh pendidikan tersebut, karena masih kurangnya inventarisasi problematika hukum pendidikan yang mengiringi. Selain itu, pemerintah harus mempersiapkan payung hukum secara menyeluruh untuk melindungi keberlangsungan proses belajar mengajar yang merupakan hak konstitusional, juga kebulatan dasar hukum menentukan ganti kerugian yang diajukan pihak tertentu harus proporsional dan layak agar, baik dalam proses hukum atau setelah proses hukum agar tidak terulang peristiwa penyegelan sekolah tersebut.

\section{Pendahuluan}

Tuhan menciptakan manusia sebagai makhluk yang memiliki pembeda daripada makhluk lainnya. Akal maupun nalar yang ada dalam diri manusia merupakan salah satu pembeda utama manusia dengan makhluk lainnya. Sebagai ciptaan Tuhan yang di anugerahi kelebihan tersebut, manusia dapat mengelola apa saja yang ada di bumi dengan menggunakan rasio berdasarkan proses penggunaan akal dan penularannya. Keberadaan akal tersebut juga memungkinkan manusia untuk dapat belajar dan mengembangkan dirinya melalui sarana yang tersedia maupun yang disediakan oleh pihak yang berurusan dengan itu.

Bentuk pengembangan diri daripada manusia adalah pembelajaran yang dirancang sedemikian rupa sehingga disebut sebagai sebuah pendidikan. Menurut UndangUndang No. 20 Tahun 2003 tentang Sistem Pendidikan Nasional (UU Sisdiknas) dapat disebutkan bahwa pendidikan merupakan suatu usaha yang sadar dan terencana untuk membuat suatu keadaan belajar beserta prosesnya agar pihak yang dididik dapat berkembang dan mempunyai kekuatan yang diinginkan dari pembuat undang-undang ini yang bermanfaat baik untuk dirinya sendiri, masyarakat, bangsa dan negara.

Pasal 9 UU Sisdiknas menyebutkan bahwa dukungan terselenggaranya pendidikan juga harus datang dari masyarakat itu sendiri. Namun dalam penjelasan pasal tersebut tidak dijelaskan bentuk dukungan masyarakat dalam penyelenggaraan pendidikan seperti apa yang diperlukan. Pendidikan di Indonesia masih dapat digolongkan sebagai sektor yang sangat perlu mendapatkan perhatian serius dari pemerintah. Data UNICEF 2016 menunjukkan 2 juta anak lebih tidak dapat mengenyam lanjutan pendidikannya ke taraf SMP yakni sekitar 1,9 juta anak dan 600 ribu ke SMA sederajat utamanya karena faktor biaya. ${ }^{1} \mathrm{Di}$ sisi lain problematika pendidikan Indonesia tidak hanya berhenti mengenai angka putus sekolah, termasuk pula terkait dengan infrastruktur bahkan juga dengan kurikulum yang sering tidak menyentuh unsur dalam pendidikan sebagaimana dimaksudkan dalam UU Sisdiknas itu sendiri.

1 Rahardlan, Ar. (2017). Tingginya Angka Putus Sekolah di Indonesia. Diakses pada https://student.cnnindonesia.com/edukasi/20170417145047-445-208082/tingginya-angkaputus-sekolah-di-indonesia/ 
Lebih jauh mengenai urgensi pendidikan dalam kehidupan bangsa bernegara memang merupakan tanggung jawab seluruh warga negara untuk dapat mendukung tercapainya tujuan pendidikan tersebut. Konstitusi UUD NRI 1945 menyebutkan dalam preambule nya yang juga mengandung tujuan negara, dalam salah satu frasanya menyebutkan "mencerdaskan kehidupan bangsa" yang berarti dengan menyelenggarakan pendidikan itu juga sejalan dengan amanat tujuan negara dalam konstitusi tersebut. Pendidikan menjadi suatu yang urgen dalam perkembangan suatu negara karena hal tersebut menentukan determinasi termasuk peradaban suatu bangsa dan negara kedepannya. Penyelenggaraan pendidikan juga memungkinkan suatu bangsa dan negara untuk dapat bersaing dalam kompetisi global yang menuntut adanya inovasi yang dihasilkan dari sistem pendidikan yang dijamin secara baik oleh pemerintah. Lebih jauh telah disebutkan dalam Pasal 31 ayat (4) UUD NRI 1945 menyebutkan prioritas bagi negara (pemerintah) harus memberikan porsi sedikitnya 20\% dari APBN dan APBD untuk pelaksanaan dan menyelenggarakan pendidikan nasional.

Salah satu permasalahan penyelenggaraan pendidikan nasional ialah adanya sejumlah permasalahan terkait dengan penggunaan tanah atau lahan untuk dijadikan sebuah sekolah. Kasus terbaru yang terjadi ialah di Kabupaten Sampang tepatnya di Desa Madulang, Kecamatan Omben di mana penyegelan dialami oleh SDN Madulang 2. Adapun kronologi penyegelan sekolah SDN Madulang 2 itu dikarenakan seseorang yaitu H. Yakub yang mengklaim pemilik daripada tanah yang berdiri di atasnya bangunan sekolah tersebut merupakan tanah tukar guling dengan lahan percaton pada tahun 1978 yang kemudian problem bermula ketika lahan tersebut kesulitan untuk didaftarkan kepemilikannya sehingga tanah seluas $1400 \mathrm{~m}^{2}$ yang didirikan bangunan sekolah tersebut kini tidak dapat dipergunakan lagi untuk proses belajar mengajar siswa dan guru. ${ }^{2}$ Penyegelan oleh warga terkait dengan sengketa kepemilikan lahan ini jelas merupakan gangguan terhadap proses pendidikan yang harusnya diperoleh oleh siswa sedangkan problematika pertanahan ini juga harusnya dapat dicegah sebelum adanya penyegelan yang berakibat hilangnya hak mendapatkan Pendidikan.

Keberadaan pihak yang mengklaim memiliki hak atas tanah di mana kemudian melakukan penyegelan terhadap bangunan sekolah yang dioperasikan oleh pemerintah merupakan satu dari banyak problematika klasik sengketa terhadap hak atas tanah di Indonesia. Perkembangan yang terjadi ialah problematika pertanahan di mana terjadi klaim hak atas tanah yang berlanjut pada tindakan penyegelan jelas merupakan ancaman terhadap keberlangsungan proses pembelajaran yang dilindungi oleh peraturan perundang-undangan terlebih mengancam hak konstitusional. Sengketa hak seperti ini merupakan warisan sejak jaman orde baru di mana kekuatan negara begitu dominan dalam proses pengambilalihan tanah atas nama kepentingan umum yang sekarang menjadi isu umum sengketa tanah yang selalu menyedot perhatian publik. ${ }^{3}$ Kasus yang dialami SDN Madulang 2 ini pun menambah panjang persoalan yang terjadi dalam dunia pendidikan di Indonesia.

Amanat konstitusi menyatakan dalam Pasal 31 ayat (1) dan (2) yang inti pokoknya merupakan hak konstitusional bagi warga negara untuk mendapat pendidikan, dan

2 Zamachsari. (2018). Sengketa, Gedung SD di Sampang Disegel Warga. Diakses pada http://beritajatim.com/hukum_kriminal/324459/sengketa,_gedung_sd_di_sampang_disegel warga.html/

3 Pahlevi. (2014). Analisis Bentuk-Bentuk Sengketa Hukum atas Tanah Menurut Peraturan Perundang-undangan di Bidang Agraria. Majalah Hukum Forum Akademika, 25 (1). 
bagi tingkat dasar adalah wajib dengan pembiayaan oleh negara. Penyegelan bangunan SD yang merupakan salah satu fasilitas dalam penyelenggaraan pendidikan dasar harusnya tidak perlu terjadi bilamana pemerintah melakukan tindakan preventif dalam mencegah hal tersebut. Kondisi atau status quo yang dipertahankan pemerintah terhadap kasus tersebut mengakibatkan ketidakpastian nasib anak yang seharusnya mendapat pengajaran dengan tenang tanpa ada gangguan yang bukan disebabkan karenanya. Kasus SDN Madulang 2 yang disegel oleh orang yang mengklaim pemilik asli lahan ini menunjukkan saling carut sengkarutnya pelaksanaan dan cara berhukum di Indonesia, yang mana di masa pasca reformasi pun masih menyisakan pelbagai problem yang terjadi 4 dekade lalu yang tidak terselesaikan dengan baik.

Problematika pertanahan di Indonesia yang masih berkutat pada bukti kepemilikan hak, di mana bahwa segala sesuatu terutama mengenai hak kebendaan di Indonesia masih sangat mengandalkan bukti otentik berupa hitam di atas putih atau dokumen-dokumen yang menunjukkan kepemilikan daripada kepercayaan apalagi kemanfaatan yang diharapkan. Oleh karenanya adalah wajar manakala prestasi normatif tidak dipenuhi maka akan terjadi kontra prestasi yang kurang lebih atau bahkan seringkali melampaui prestasi yang dilanggar. Cara berhukum semacam itu sama dengan mendewakan hukum dari luarnya saja yakni peraturan-peraturan saja yang utama daripada faktorfaktor dibalik pembangunan hukum tersebut. Padahal, bilamana hukum hanya dipahami sebagai aspek normatif semata, maka konflik yang berpotensi merenggut hak pendidikan semacam ini akan terus terjadi, terlebih pemahaman terhadap tata berhukum atau bahkan praktik hukum di masa orde baru yang dominan penguasaan pemerintah tidak dipahami sebagai hambatan dalam upaya memikirkan terobosan hukum apa yang perlu dilakukan dan manfaat apa saja yang diperoleh dari pihak yang berkonflik bila diambil suatu putusan tertentu. Pemikiran hukum progresif memiliki pijakan filsafatis bahwa hukum adalah untuk manusia dan tidak akan sebaliknya, yang menyoroti hukum dari aspek manfaatnya terhadap sosial kemasyarakatan dan perilaku manusia daripada hanya sekedar mengartikan teks atau hanya berkutat pada analytical jurisprudence semata. ${ }^{4}$

Penelitian terdahulu yang berkaitan dengan penulisan ini ialah dari Gia Felicia Putri dalam Diponegoro Law Journal Vol 5 No. 3 Tahun 2016 yang menyoroti secara empiris penyelesaian problematika sengketa tukar menukar tanah dalam proses pembangunan prasarana pendidikan yakni SDN 3 Pakintelan Gunungpati Semarang, di mana menyoroti permasalahan mengapa terjadi sengketa tanah dan penyelesaian sengketa tukar menukar dalam prasarana pendidikan. ${ }^{5}$ Sedangkan penulisan ini akan menyoroti secara normatif akibat status quo tanah tukar guling yang statusnya belum jelas dikaitkan dengan hilangnya hak pendidikan murid SDN Madulang 2 akibat penyegelan oleh klaim pemilik. Permasalahan itu akan diangkat dalam perspektif hukum progresif dan hak asasi manusia terhadap potensi kerugian hak dasar yakni memperoleh pendidikan akibat peristiwa hukum semacam ini, dan rendahnya diseminasi HAM dalam bidang pendidikan di tengah masyarakat.

\footnotetext{
${ }^{4}$ Rahardjo, S. (2009). Hukum Progresif Sebuah Sintesa Hukum Indonesia. Malang: Genta Publishing, h. 1, 10.

${ }^{5}$ Putri, G.F. \& Ana Silviana, S. (2016). Penyelesaian Sengketa Tukar Menukar Tanah dalam Pembangunan Prasarana Pendidikan: Studi Kasus di SDN 03 Pakintelan, Gunungpati, Semrang. Diponegoro Law Journal, 5(3), h. 1.
} 


\section{Metode Penelitian}

Penulisan ini menggunakan tatacara metode penelitian normatif di mana merupakan salah satu dari jenis penelitian hukum. Penelitian hukum normatif bertujuan untuk mencari solusi dari problematika yuridis yang muncul dari isu hukum dan memberikan preskripsi terhadap isu hukum tersebut. ${ }^{6}$ Penelitian hukum bertujuan mencapai kebenaran koherensi yakni apakah suatu aturan hukum telah sejalan dengan norma hukumnya, ataukah norma hukum tersebut koheren bila disandingkan dengan prinsip hukum, ataukah tindakan seseorang telah mencapai kesesuaian bila dilihat dari norma hukum (tidak hanya sesuai atau tidaknya dengan aturan hukum) dan atau prinsip hukum. ${ }^{7}$ Penelitian yang ditujukan dalam penulisan ini ialah melihat dari aspek yuridis peraturan perundang-undangan yang akan dianalisis dengan menggunakan teori hukum progresif untuk menemukan sejauh mana peraturan perundang-undangan tersebut dapat memberikan kemanfaatan bagi masyarakat didasarkan pada data-data valid yang diperoleh untuk kemudian diberikan preskripsi terkait problematika dari perundang-undangan yang dianalisis dengan menggunakan teori tersebut.

\section{Hasil dan Pembahasan}

\subsection{Jaminan dan Perlindungan Hak Asasi Manusia di Bidang Pendidikan}

Universal Declaration of Human Rights (UDHR) merupakan Deklarasi mengenai Hak Asasi Manusia PBB yang berisikan muatan pengakuan pada hak asasi manusia (HAM). Deklarasi tersebut memuat pengakuan atas berbagai hak dasar manusia tidak terkecuali mengenai pendidikan. Pendidikan secara khusus memiliki dasar yuridis dalam Pasal 26 UDHR, yaitu bahwa pendidikan merupakan hak dasar bagi manusia setidaknya pada tahap awal dan dasar untuk pengembangan kepribadian manusia memberikan pengertian toleransi dan persaudaraan. Deklarasi tersebut merupakan sebuah instrumen dalam ranah hukum internasional mengenai HAM yang memiliki sifat morally binding, berkaitan dengan bentuknya sebagai deklarasi. Walaupun UDHR hanya sebuah deklarasi yang tidak memiliki kekuatan mengikat, namun instrumen tersebut dapat menjadi dasar dari banyaknya peraturan perundang-undangan mengenai HAM di seluruh dunia tidak terkecuali di Indonesia.

Semangat pemenuhan hak pendidikan di Indonesia bukan hal baru yang lahir setelah kemerdekaan. Peran Boedi Utomo sangat besar artinya dalam perkembangan pemikiran HAM di bidang pendidikan pada masa pra-kemerdekaan. ${ }^{8}$ Lahirnya Boedi Utomo memiliki tujuan untuk mengusahakan "Kemajuan bagi Hindia". Pengurus organisasi ini memutuskan tidak melibatkan diri dalam kegiatan politik, melainkan berfokus pada bidang pendidikan dan budaya. ${ }^{9}$ Secara historis, konsep HAM dalam hal pendidikan mengalami perkembangan, bercermin pada preambule UUD 1945 di mana tertulis pemerintah Indonesia memiliki tugas mencerdaskan kehidupan bangsa. Sedangkan

\footnotetext{
${ }^{6}$ Susanti, D.O., \& Efendi, A. (2014). Penelitian Hukum: Legal Research. Jakarta: Sinar Grafika, h. 1.

${ }^{7}$ Marzuki, P. M. (2005). Penelitian Hukum (Edisi Revisi). Jakarta: Kencana, h. 47.

8 Manan, Bagir. (2001). Perkembangan Pemikiran dan Pengaturan Hak Asasi Manusia di Indonesia. Bandung: Alumni, h. 63.

${ }^{9}$ Ibid., h. 64.
} 
menilik ke Konstitusi RIS dan UUD Sementara 1950, pemikiran HAM di bidang pendidikan tercermin dalam hak-hak kebebasan dasar manusia. ${ }^{10}$

Negara dengan sifat khususnya dapat melakukan pemaksaan, memonopoli, dan kesemuanya itu sebagai satu-satunya organisasi yang memiliki kedaulatan untuk yaitu hak untuk mengatur (to regulate) dan memaksakan (to enforce) kebijakan dari bermacam bentuk peraturan yang mana berujung untuk dan atas nama daripada masyarakat itu sendiri. Berdasarkan adanya kekuasaan yang melekat pada negara tersebut kemudian memunculkan otoritas untuk mendesak untuk adanya hukum yang akhirnya melindungi pada hak asasi tiap-tiap warga negara, spesifik pada perolehan hak mengeyam pendidikan. ${ }^{11}$ Pendidikan menjadi satu hal yang penting sebagai tolok ukur pembangunan dan kesejahteraan suatu negara. Sehingga negara selalu dituntut hadir dalam menjawab tantangan untuk menjamin terlaksananya hak dasar untuk mendapatkan pendidikan. Langkah yang ditunjukkan pemerintah tidak hanya meratifikasi deklarasi universal HAM, namun menyusun beberapa instrumen hukum yang bertujuan berusaha dan menjamin terselenggaranya suatu pendidikan dalam rangka mencerdaskan kehidupan bangsa. Instrumen hukum di Indonesia yang secara eksplisit menjamin hak dasar warga negaranya untuk mendapatkan pendidikan yang layak dapat diintisarikan sebagai berikut:

1. Dasar Konstitusional, Undang-Undang Dasar Negara Republik Indonesia Tahun 1945 (UUD NRI 1945), pada preambule-nya menyatakan kewajiban negara untuk "mencerdaskan kehidupan bangsa", Pasal 28 C ayat (1) mengenai hak untuk mendapatkan pendidikan, Pasal 28 I ayat (4) mengenai kewajiban negara utamanya dalam pemenuhan (fulfilling) hak asasi manusia, hingga keharusan prioritas prosentase dalam APBN sekurang-kurangnya yakni 20\% untuk kebutuhan terelenggaranya pendidikan nasional pada pasal 31 ayat (4).

2. Pasal 12, Undang-Undang No. 39 Tahun 1999 tentang Hak Asasi Manusia (UU HAM), yang mengatur bahwa setiap orang diberikan perlindungan dalam pengembangan dirinya dalam ranah pendidikan sesuai cakupan hak asasi manusia.

Selain dalam Pasal diatas, ketentuan mengenai pendidikan juga diatur dalam beberapa pasal dalam UU HAM, yakni Pasal 42, Pasal 48, Pasal 54, dan Pasal 60. Dari pasal-pasal tersebut disebutkan bahwa frasa pendidikan yang harus diperoleh sebagai hak dasar bagi warga negara, baik itu anak-anak, wanita maupun penyandang cacat berhak mendapatkan pendidikan termasuk pengaturan mengenai setiap pihak berhak melakukan penyelenggaraan pendidikan yang sesuai peraturan perundang-undangan. Pendidikan dilaksanakan dalam negara bertujuan tidak lain untuk meningkatkan kemampuan manusia Indonesia dengan tujuan mencapai daya saing yang sama dengan negara lain dan yang paling esensial ialah upaya dalam peningkatan pembangunan sumber daya manusia Indonesia seutuhnya dari pendidikan tersebut.

3. Undang-Undang Nomor 20 Tahun 2003 tentang Sistem Pendidikan Nasional

UU Sisdiknas lahir beserta ekspektasi untuk dapat dan mampu melakukan jaminan pemerataan kesempatan dalam memperoleh pendidikan, meningkatnya mutu serta

${ }^{10} \mathrm{Ibid} .$, h. 69-70.

${ }^{11}$ Sujatmoko, E. (2010). Hak Warga Negara dalam Memperoleh Pendidikan. Jurnal Konstitusi, $7(1)$, h. 200-201. 
terwujudnya relevansi dan efisiensi penyelenggaraan manajemen pendidikan dalam menghadapi tantangan yang ada yaitu tuntutan perubahan kehidupan mulai tarif lokal, nasional, dan global sehingga penting melakukan pembaharuan secara terencana, terarah dan berkesinambungan.

4. Peraturan Pemerintah Nomor 19 Tahun 2005 tentang Standar Nasional Pendidikan (PP SNP) sebagaimana diubah dengan Peraturan Pemerintah Nomor 32 Tahun 2013 dan Peraturan Pemerintah Nomor 13 Tahun 2015.

PP SNP merupakan ketentuan lebih lanjut pengaturan Pasal 35 UU Sisdiknas. Peraturan Pemerintah ini mengatur bagaimana standarisasi isi, proses, kompetensi, tenaga kependidikan, sarana dan prasarana, pengelolaan, pembiayaan dan penilaian dari sistem pendidikan.

5. Peraturan Menteri Pendidikan Nasional Nomor 24 Tahun 2007 tentang Standar Sarana dan Prasarana untuk Sekolah Dasar /Madrasah Ibtidaiyah (SD/MI), Sekolah Menengah Pertama/Madrasah Tsanawiyah (SMP/MTs) dan Sekolah Menengah Atas/Madrasar Aliyah (SMA/MA) (Permendiknas 24/2007).

Hak dasar dalam memperoleh pendidikan merupakan satu dari pelbagai hak yang keberlangsungannya harus dijamin oleh negara atau pemerintah. ${ }^{12} \mathrm{Hal}$ ini sebagai konsekuensi logis seseorang menjadi warga negara di suatu negara untuk mendapat jaminan termasuk terlindunginya hak yang melekat sesuai konstitusional. Peran dan tanggungjawab pemerintah menjadi faktor penting dalam mewujudkan pendidikan yang layak. Tanggungjawab pemerintah dalam hal pendidikan tersebut terdapat dalam UU Sisdiknas, yakni Pasal 11 ayat (2), Pasal 34 ayat (2), Pasal 34 ayat (3), Pasal 34 ayat (4), Pasal 46 ayat (1), Pasal 46 ayat (3), Pasal 47 ayat (2) dan Pasal 47 ayat (3). Secara implisit, pasal tersebut menunjukkan bahwa dalam menyelenggarakan pendidikan, tanggungjawabnya bukan hanya persoalan kewenangan di Pemerintah Pusat maupun Pemerintah Daerah, melainkan menjadi tanggungjawab masyarakat juga. Peran ketiganya terlihat pada aspek pendanaan pendidikan, di mana pemerintah mendanai dari APBN dan/atau APBD sedangkan masyarakat mencakup sumbangan pendidikan, pemberian hibah, wakaf, penyaluran zakat, pembayaran nazar, pinjaman, sumbangan perusahan, pemberian pengurangan atau bahkan dihapuskannya pajak untuk penyelenggaraan pendidikan dan penerimaan yang sah lainnya. ${ }^{13}$

Pemerintah setiap tahunnya menganggarkan 20\% untuk bidang pendidikan. Pada 2018, alokasi anggaran fungsi pendidikan oleh pemerintah yakni Rp 440,9 triliun atau dapat dikatakan sejumlah 20\% dari APBN. Sebanyak 279,3 triliun dari anggaran fungsi pendidikan di APBN tersebut disalurkan tertuju pada daerah yang melakukan pemenuhan kebutuhan bidang penyelenggaraan pendidikan di Indonesia. ${ }^{14}$ Selain itu, pemerintah juga mengeluarkan kebijakan prioritas yaitu membantu terbangunnya infrastruktur sekolah yang merupakan program prioritas nasional pendidikan yang

12 Qamar, Nurul. (2014). Hak Asasi Manusia dalam Negara Hukum Demokrasi (Human Rights in Democratiche Rechsstaat). Jakarta: Sinar Grafika, h. 17.

13 Sujatmoko, E. Op.Cit., h. 202.

${ }^{14}$ Kementerian Pendidikan dan Kebudayaan. (2018). Media Komunikasi dan Inspirasi Jendela Pendidikan dan Kebudayaan: 279 Triliun Pembiayan Pendidikan Ditransfer ke Daerah. Edisi $\begin{array}{lllll}\text { XXVI/Agustus } & 2018, & \text { h. } & 7 . & \text { Diakses }\end{array}$ pada http://jendela.kemdikbud.go.id/assets/public/EDISI 26_2018.pdf 
setiap tahun terlaksana dengan sasaran sekolah pada semua jenjang. ${ }^{15}$ Program-program tersebut masih bertumpu pada bantuan perbaikan atau rehab dan pembangunan sarana dan prasarana pendidikan yang memiliki urgensi tersendiri dalam terpenuhinya sarana terlebih prasarana yang memadai. Namun, kelalaian yang terjadi ialah permasalahan status hak atas tanah di mana bangunan sekolah tersebut berdiri. Langkah preventif dalam tertib administratif terabaikan oleh target pembangunan sekolah saja, namun mengaburkan kepastian akan status tanah di mana sekolah tersebut dibangun.

Permasalahan di dunia pendidikan semakin beragam, tidak hanya mengenai anggaran pendidikan, sumber daya manusia dan sistem pendidikan, melainkan sampai pada ranah sengketa lahan sekolah. Sengketa lahan sekolah tidak hanya ditemui satu kasus saja, melainkan terjadi di beberapa daerah. Berdasarkan catatan dari Dinas Pendidikan Kabupaten Pemaksaan pada tahun 2010, telah terjadi lima kasus sengketa lahan sekolah dengan warga. Dari lima kasus tersebut tiga di antaranya terjadi penyelegelan, potensi sengketa yang sama juga terlihat di mana terdapat sekitar 600 lembaga Pendidikan untuk taraf SD dan SMP, sebanyak 273 sekolah yang hak lahannya belum dilindungi dengan kepemilikan sertifikat sehingga memunculkan kemungkinan dapat disengketakan oleh pihak tertentu. ${ }^{16}$ Kasus yang sama juga terjadi pada tahun 2016, di mana SDN Karangasem 1 Jawa Tengah disegel oleh ahli waris pemilik tanah. ${ }^{17}$ Pada tahun 2017, penyegelan sekolah terjadi di SMAN 2 Tanjung Selor18, SDN 11 Makassar, SMAN 4 Makassar dan SMPN 9 Pare-pare ${ }^{19}$ dan tahun 2018, SDN Kranggan 1 Kota Mojokerto, Jawa Timur ${ }^{20}$ dan SDN Madulang 2, Sampang21. Tidak berhenti pada tahun 2018, pada tahun 2019 sengketa yang berujung penyegelan juga terjadi di SD Negeri 48/VI Desa Biuku Tanjung, Kecamatan Bangko Barat, Kabupaten Merangin, Jambi. ${ }^{22}$

Tindakan penyegelan tersebut merupakan contoh sengketa lahan sekolah yang terekspos di media, tidak menutup kemungkinan masih banyak kasus yang sama terjadi

${ }^{15}$ Kementerian Pendidikan dan Kebudayaan. (2018). Media Komunikasi dan Inspirasi Jendela Pendidikan dan Kebudayaan: Bantuan Pembangunan Infrastruktur Sekolah, Wujud Perhatian Pusat ke Daerah. Edisi XXVI/Agustus 2018, h. 14.

Diakses pada http://jendela.kemdikbud.go.id/assets/public/EDISI 26_2018.pdf

16 Tempo.co. Sengketa Lahan Sekolah Jadi Momok Bagi Dunia Pendidikan. Diakses pada https://nasional.tempo.co/read/249952/sengketa-lahan-sekolah-jadi-momok-bagi-duniapendidikan.

17 Ellya. Penyelesaian Sengketa SD Karangasem Tempuh Jalur Hukum. diakses pada http:// beritajateng.net/penyelesaian-sengketa-tanah-sd-karangasem-tempuh-jalur-hukum/

18 Koran Kaltara. Bupati Pastikan Segera Tuntaskan Lahan Sekolah. Diakses pada http:// www.korankaltara.co/read/news/2017/29181/bupati-pastikan-segera-tuntaskansengketa-lahan-sekolah.html

19 Darwiaty Dalle. DPRD Minta Pemerintah Daerah Tuntaskan Sengketa Lahan Sekolah. Sindonews.com. diakses pada https://makassar.sindonews.com/read/76/1/dprd-mintapemerintah-daerah-tuntaskan-sengketa-lahan-sekolah-1508256644

${ }^{20}$ Budi Widayat. Lahan Sekolah Masih Sengketa, Ratusan Siswa di Mojokerto Mengungsi. Diakses pada https://www.merdeka.com/peristiwa/lahan-sekolah-masih-sengketa-ratusansiswa-sd-di-mojokerto-ngungsi.html

${ }^{21}$ Jawapos.com. Siswa SDN Madulang 2 Belajar di Tempat Parkir Motor. Diakses pada https://radarmadura.jawapos.com/read/2018/03/28/60556/siswa-sdn-madulang-2-belajardi-tempat-parkir-motor

22 Sindonews.com. Tanah Sekolah Disegel Ratusan Siswa Tak Bisa Sekolah. Diakses pada https://daerah.sindonews.com/read/1372427/174/tanah-sekolah-disegel-ratusan-siswa-takbisa-sekolah-1548092523 
di daerah lain. Sengketa lahan tersebut patut disayangkan karena terjadi di beberapa sekolah yang berstatus negeri. Dampak yang ditimbulkan dari sengketa tidak hanya mengganggu kegiatan belajar mengajar, namun memiliki dampak jangka panjang. Hal tersebut mengingat faktor apakah terdapat sarana dan prasarana sekolah yang kurang memadai mengakibatkan penurunan minat dari siswa untuk belajar bahkan dapat meningkatkan angka putus sekolah.

Periode bulan April sampai dengan Juli 2018, Komisi Perlindungan Anak Indonesia (KPAI) yang mengawasi bidang pendidikan mendapatkan laporan sejumlah 33 kasus terlanggarnya hak anak ketika di sekolah. Kasus tersebut mulai dari, korban kebijakan sebanyak 10 kasus (30,30\%); adanya pungutan liar di sekolah 2 kasus atau 6,60\%; tidak dibolehkannya anak mengikuti ujian 2 kasus (6,60\%); tersegelnya sekolah 1 kasus (3,30\%); putus sekolah dan dikeluarkan dari sekolah 5 kasus (15\%); dan yang tertinggi adalah korban kekerasan (bully) 13 kasus (39\%). ${ }^{23}$ Penyegelan sekolah merupakan satu dari sederetan kasus pelanggaran hak anak yang telah dilaporkan ke KPAI dengan jumlah presentae $3.30 \%$. Tindakan tersebut masuk dalam kategori melanggar hak anak karena dinilai menghalangi anak untuk memperoleh pendidikan, mencerdaskan dan meningkatkan kualitas hidup serta mendapat pengajaran dalam rangka pengembangan pribadi sebagaimana ketentuan dalam Pasal 12 jo. Pasal 60 ayat (1) UU HAM.

Sengketa lahan sekolah bersumber dari terabaikannya prinsip tertib dalam administrasi pertanahan. Pemerintah Pusat maupun Pemerintah Daerah yang memiliki kewenangan di bidang pendidikan seharusnya melakukan langkah preventif dengan melakukan penertiban data pendirian sekolah sesuai standar yang ditentukan. Pasal 42 ayat (2) PP SNP yang pada pokoknya menyebutkan bahwa satuan pendidikan diwajibkan mempunyai pelbagai prasarana yang dibutuhkan untuk menunjang proses pembelajaran dari lahan, ruang kelas, pimpinan, pendidik, perpustakaan, laboratorium, tempat olahraga, tempat ibadah dan lainnya.

Prasarana berupa lahan untuk bangunan sekolah berdasarkan pasal tersebut merupakan suatu kewajiban yang dimiliki oleh satuan pendidikan. Lahan yang dimaksud ialah lahan untuk bangunan sekolah dan lahan untuk prasarana penunjang lainnya. Untuk mengakomodir anak dengan mudah mendapatkan haknya berupa pendidikan, standar letak lahan satuan pendidikan diatur dalam Pasal 44 PP SNP. Letak lahan haruslah ditimbang berdasarkan jarak tempuh terjauh yang dilalui peserta didik untuk sampai ke lokasi pendidikan dan dipertimbangkan segi keamanan, kenyamanan dan kesehatan lingkungan. Hal inilah juga menjadi dasar untuk mempertahankan lingkungan sekolah yang sudah terbentuk bertahun-tahun, selain atas dasar tata ruang dan pertimbangan jarak tempuh juga dipertimbangkan kondisi keamanan, kenyamanan dan kesehatan lingkungan di mana sekolah berdiri. Tanpa sarana dan prasarana pendidikan, proses pendidikan akan mengalami kesulitan dan secara impulsif dapat mengaburkan tujuan dari pendidikan itu sendiri.

\subsection{Signifikansi Problematika Pertanahan pada Prasarana Pendidikan}

Kebijakan nasional perihal pertanahan sebelumnya telah mendapatkan Ketetapan MPR RI Nomor II/MPR/1998 tentang Garis-Garis Besar Haluan Negara yang pada pokoknya

${ }^{23}$ KPAI. Pers Release Ekspose Pengawasan KPAI Bidang Pendidikan April-Juli 2018 Trauma. Diakses pada http://www.kpai.go.id/berita/pers-release-ekspose-pengawasan-kpai-bidangpendidikan-april-juli-2018-trauma-berat-cedera-fisik-sampai-kematian-akibat-kekerasan-di$\underline{\text { sekolah }}$ 
menyatakan bahwa segala penguasaan dan penataan tanah diharuskan untuk mengarah pada tujuan keadilan sosial, dimana pemanfaatannya melibatkan kepentingan masyarakat luas dan tidak memunculkan sengketa. Proses penataan harus memperhatikan kaitan dengan hak tanah, fungsi sosial, hingga luasan yang ditentukan untuk mencegah terpusatnya kepemilikan tanah yang berujung pada terlantarnya bidang tanah tersebut. Dalam TAP MPR terkait pertanahan tersebut juga dalam pembangunan terhadap tanah harus melihat pelbagai aspek mulai dari poleksosbud termasuk dengan lingkungan hidup yang kemudian dilakukan redistribusi tanah yang telah tertata untuk menunjang dan mempercepat pengentasan kemiskinan dan kesenjangan dalam pertanahan.

Poin penting yang dapat digaris bawahi dari isi ketetapan tersebut mengenai kebijakan nasional di ranah pertanahan adalah penguasaan dan penataan tanah oleh negara. Hal senada sebelumnya sudah diatur dalam Pasal 2 ayat (2) Undang-Undang Nomor 5 tahun 1960 tentang Peraturan Dasar Pokok-Pokok Agraria (UUPA), di mana kewenangan ada pada negara untuk mengatur, mengorganisasi peruntukan, penggunaan tanah, persediaan dan pemeliharaan bumi, air, hingga ruang angkasa. Hak negara ini adalah hak penguasaan tanah yang tertinggi dimana meliputi semua aspek yang ada di wilayah negara yang berupa tanah bersama, bersifat abadi dan merupakan induk bagi bentuk hal lain atas tanah ketika melakukan kegiatan penguasaannya. ${ }^{24} \mathrm{Hak}$ menguasai oleh negara terhadap tanah ditentukan pembatasannya yaitu:25

1. Negara tidak dapat mengesampingkan hak atas tanah yang telah ada oleh warga negara, badan hukum termasuk warga negara asing yang berkedudukan di Indonesia;

2. Berdasarkan keperluan dan kepentingannya negara memiliki kuasa penuh atas pemberian lahan tanah berupa hak pada warga negara Indonesia atau badan hukum bilamana ada tanah yang tidak dipunyai hak oleh siapapun.

Dalam Pasal 18 UUPA kembali dijelaskan bahwa yang termasuk ketentuan yang ada dii Pasal 2 ayat (2) UUPA, ialah untuk kepentingan bersifat umum, yaitu kepentingan yang digunakan untuk bangsa dan negara serta kepentingan yang bersifat bersama yang asalnya dari rakyat, hak tanah dapat diambil kembali melalui diberikannya ganti rugi yang sesuai dan berdasarkan tatacara sesuai dengan hukum. Konsep kepentingan umum menurut Maria S.W. Soemardhono berpendapat bukan hanya untuk menyesuaikan peruntukan atau kebutuhannya namun juga rasa kemanfaatan oleh sosial atau publik harus ada dan supaya unsur tujuan kemanfaatan dapat diperoleh secara penuh, maka seyogyanya diadakan suatu penelitian terpadu. ${ }^{26}$ Kepentingan umum yang dimaksud di atas diatur dalam Pasal 10 Undang-Undang No. 2 Tahun 2012 tentang Pengadaan Tanah Bagi Pembangunan untuk Kepentingan Umum (UU No. 2 Tahun 2012), yang menerangkan bahwa tanah yang terkait dalam problematika ini adalah untuk pembangunan salah satunya dalam butir $\mathrm{p}$ disebutkan untuk prasarana pendidikan atau sekolah yang diadakan oleh Pemerintah/Pemerintah Daerah.

${ }^{24}$ Santoso, Urip. (2012). Hukum Agraria Kajian Komprehensif. Jakarta: Kencana, h. 78.

${ }^{25}$ Santoso, Urip. (2011). Pendaftaran Tanah dan Peralihan Hak Atas Tanah. Jakarta: Kencana, h. 121.

${ }^{26}$ Hamdi. (2014). Penyelesaian Sengketa Penetapan Ganti Rugi dalam Pengadaan Tanah untuk Pembangunan Kepentingan Umum (Kajian Terhadap Undang-Undang Nomor 2 Tahun 2012). Jurnal IUS Kajian Hukum dan Keadilan, 2(4), h. 87. 
Berdasarkan pasal 10 tersebut khususnya pada huruf p UU No. 2 Tahun 2012, menyebutkan secara eksplisit prasarana pendidikan atau sekolah Pemerintah/Pemerintah Daerah merupakan satu dari kategori kepentingan umum yang dapat menjadi dasar dapat dicabutnya kembali hak atas tanah untuk keperluan pembangunan. Ketentuan tersebut merupakan dasar bagi Pemerintah untuk melakukan penataan kembali sekolah-sekolah yang didirikan di atas tanah yang kepemilikannya pribadi.

Pencabutan hak tanah tersebut tentu saja tidak dapat dilakukan secara semena-mena, karena terdapat hak seseorang yang juga harus dihormati. Di sisi lain terdapat hak keperdataan seseorang yang dipertahankan. Hukum keperdataan mengharuskan adanya kewajiban dasar manakala seseorang tersebut mengambil suatu hak bagi orang lain pula, yakni hak untuk mendapatkan penghormatan atas hak asasinya dari orang lain secara moral, etika dan tata tertib kehidupan dalam tataran bermasyarakat, berbangsa dan bernegara. ${ }^{27}$ Oleh karena itu, untuk proses pencabutan hak atas tanah yang dilakukan atas dasar peraturan di Undang-Undang Nomor 20 Tahun 1961 tentang Pencabutan Hak-hak Atas Tanah dan Benda-benda yang Ada di atasnya, di mana proses pencabutan hak ini harus selayaknya dan seadil-adilnya suatu pemberian ganti rugi. ${ }^{28}$

Ganti kerugian adalah proses penggantian dengan layak dan adil teruntuk pihak yang mempunyai hal dalam proses pengadaan tanah. Pengadaan tanah untuk kepentingan umum dilakukan bukan tanpa perencanaan. Kegiatan tersebut dilakukan beberapa tahapan seperti rencana tata ruang wilayah, rencana pembangunan di tingkat Nasional/Daerah. Persoalan ganti rugi dalam pengadaan tanah menjadi salah satu penyebab terjadinya masalah yang memiliki kemungkinan dapat menghambat pengadaan tanah. Rakyat memiliki persepsi berdasarkan pengalaman subyektif terjadinya penerimaan harga tanah yang tidak dapat di akseptasi mereka, karena ditetapkan oleh pemerintah yang mereka anggap terlalu rendah atau tidak sesuai harga pasaran sebagaimana yang sering terjadi dan tidak dapat memperoleh jaminan pemenuhan kehidupan keberlanjutan yang sejahtera, sehingga terjadi sengketa di kemudian hari. ${ }^{29}$

Sengketa pertanahan terjadi karena berbedanya pendapat satu pihak yang memiliki kepentingan mengenai sahnya suatu hak, pemberian dan hak atas tanah yang didaftarkan termasuk pula peralihan dan penerbitan suatu tanda bukti haknya termasuk pula pihak lain yang memiliki kepentingan dan merasa memiliki hubungan hukum serta pihak lain yang memiliki kepentingan juga dapat terpengaruh dikarenakan status hukum tanah tersebut. Sengketa di bidang pertanahan bukanlah hal asing yang baru saja terjadi dewasa ini. Permasalahan pertanahan terus terjadi berlarut-larut, mengingat sejarah yang menunjukkan adanya pluralisme hukum tanah pada masa kolonial belanda, sistem kepemilikan, dan sistem pencatatan dan pendaftaran yang memiliki kelemahan serta jumlah lahan yang tetap (terbatas) dengan perbandingan jumlah penduduk yang bertambah, menjadi pemicu sengketa tanah yang

${ }^{27}$ Hartono, S. R. (2009). Hak Asasi Manusia: Dalam Perspektif Hukum Perdata Sepanjang Masa. Bandung: Refika Aditama, h.162.

${ }^{28}$ Lihat Pasal 18 UUPA jo. UU No. 20 Tahun 1961 tentang Pencabutan Hak-hak Atas Tanah dan Benda-Benda yang Ada di Atasnya jo. Pasal 5 UU No. 2 Tahun 2012 tentang Pengadaan Tanah Bagi Pembangunan untuk Kepentingan Umum jo. Pasal 12 Peraturan Presiden No. 71 Tahun 2012 tentang Pengadaan Tanah Bagi Pelaksanaan Pembangunan untuk Kepentingan Umum.

${ }^{29}$ Hamdi. Op., Cit., h. 81. 
berkepanjangan. Hal tersebut berkaitan dengan tanah sebagai kebutuhan mendasar menopang berbagai aktifitas hidup seseorang yang memiliki fungsi sebagai social asset dan capital asset, ${ }^{30}$ sehingga banyak kepentingan yang berdiri di atasnya.

Sifat dari sengketa tanah sendiri memiliki beberapa tipe, yakni: ${ }^{31}$

1. Problem terkait prioritas yang bisa ditetapkan sebagai pemegang hak atas tanah yang sah dari tanah yang belum ada haknya;

2. Adanya pihak yang mengelak terhadap alas hak/bukti perolehan yang dijadikan dasar diberikannya hak;

3. Kekeliruan/kesalahan hak yang diberikan dari sebab penerapan peraturan yang kurang/tidak benar;

4. Sengketa lain yang terdapat aspek sosial dalam aplikasi praktis (strategis).

Maria Sumardjono, membagi jenis sengketa pertanahan menjadi 5 (lima) kelompok yakni: 32

1. Kasus yang berkaitan mengenai pengerjaan rakyat atas di area perkebunan, hutan dll.;

2. Kasus yang mengenai penyimpangan landreform;

3. Kasus yang terjadi karena ekses proses penggunaan tanah untuk pembangunan;

4. Sengketa yang bersifat keperdataan terkait dengan masalah tanah;

5. Sengketa mengenai hak ulayat.

Delapan tipologi kasus pertanahan menurut BPN yaitu:33

1. Dikuasai dan/atau dimilikinya bidang tanah;

2. Penetapan hak dan/atau pendaftaran tanah;

3. Penentuan batas dan/atau posisi suatu bidang tanah;

4. Proses pengadaan/pembebasan tanah

5. Tanah yang dijadikan objek landreform;

6. Adanya tuntutan ganti rugi pada tanah partikelir;

7. Tanah yang terdapat hak ulayat/adat;

8. Proses dilaksanakannya putusan pengadilan;

Pengelompokan sengketa pertanahan tersebut merupakan sengketa pertanahan secara umum. Di mana belum bisa dipetakan pihak mana saja yang terkait dan apa koordinasi dengan cara-cara yang diperlukan beserta langkah kebijakan yang seharusnya dilakukan untuk menangani sengketa pertanahan. ${ }^{34}$ Dalam lingkup sengketa pertanahan yang diperuntukkan kepentingan umum atau dapat disebut juga sengketa antar masyarakat dan pemerintah adalah sengketa yang berkaitan dengan kasus yang terdapat ekses-ekses di dalam proses penyediaan tanah untuk pembangunan, pengadaan/pembebasan tanah, pengaturan tanah objek landreform dan berkenaan dengan tuntutan ganti rugi tanah.

${ }^{30}$ Istanti \& Khisni, A. (2017). Akibat Hukum Dari Akta Jual Beli Tanah di Hadapan PPAT yang dibuat Tidak Sesuai dengan Prosedur Pembuatan Akta PPAT. Jurnal Akta, 4(2), h. 271.

${ }^{31}$ Murad, R. (1991). Penyelesaian Sengketa Hukum Atas Tanah. Bandung: Mandar Maju, h. 22.

32 Ahmad, Ibrahim. Prinsip Keadilan dalam Penyelesaian Sengketa Tanah untuk Kepentingan Pembangunan. Jurnal Legalitas, 3(2), h. 20

33 Kementerian PPN/Bappenas. (2013). Kebijakan Pengelolaan Pertanahan Nasional. White Paper, h. 6.

34 Ibid. 
Sengketa lahan sekolah sebagaimana disebutkan sebelumnya merupakan contoh permasalahan tanah yang berkaitan dengan kepentingan umum mengenai prasarana pendidikan atau sekolah. Standar sarana ataupun prasarana untuk sekolah sebenarnya telah diatur dalam Permendiknas 24/2007. Dalam lampiran ketentuan tersebut ditentukan kriteria minimum sarana dan prasarana. Kriteria minimum sarana yang diperlukan sekolah dapat dirinci mulai dari mebeulair, alat dan pendidikan, sumber belajar berupa buku maupun bentuk lain, tersedianya teknologi informasi dan komunikasi, termasuk perlengkapan lain yang harus ada di setiap sekolah/madrasah. Sedangkan untuk persyaratan minimal dalam ranah prasarana terdiri dari lahan, bangunan, ruangan, kelistrikan dan jasa yang wajib dimiliki oleh setiap sekolah/madrasah.

Lebih lanjut ditentukan dalam Permendiknas 24/2007, bahwa tanah atau lahan yang digunakan harus sesuai dengan perencanaan guna lokasi yang diatur dalam Peraturan Daerah tentang RTRW atau perencanaan lain yang lebih rinci dan bersifat mengikat, dan memperoleh izin untuk memanfaatkan tanah dari pemerintah daerah setempat. Tanah atau lahan yang terdapat hak atas tanah, dan/atau mempunyai izin untuk memanfaatkan dari pemegang hak atas tanah sesuai ketentuan hukum yang berlaku untuk menggunakannya paling sedikit 20 tahun. Bangunan sekolah diberikan kelengkapan izin mendirikan bangunan dan izin gangguan sesuai ketentuan hukum yang ada. Jika standar yang ditetapkan tersebut dilaksanakan sebagaimana mestinya dengan tidak mengesampingkan izin pemanfaatan dari pemerintah daerah, pemagang hak dan izin mendirikan bangunan, maka sengketa lahan dapat diminimalisir sehingga tidak ada tindakan penyegelan sekolah.

Sengketa lahan sekolah memang memiliki pola yang sedikit berbeda dengan sengketa pertanahan yang dilakukan dengan tujuan kepentingan umum atau lainnya. Jika pembangunan yang ditujukan untuk kepentingan umum dilakukan dengan kesepakatan peralihan dan penetapan ganti kerugian terlebih dahulu, kemudian dilakukan serangkaian proses pengadaan tanah. Sedangkan sengketa lahan sekolah terjadi ketika pemanfaatan lahan tersebut telah terjadi bertahun-tahun namun di kemudian hari pemegang hak atas tanah muncul untuk meminta ganti rugi. Tanah yang diperuntukkan untuk bangunan sekolah mayoritas berasal dari proses hibah, yang dilakukan secara lisan atas dasar kepercayaan, tanpa adanya proses pencatatan ataupun peralihan hak. Selain itu sengketa lahan sekolah disebabkan proses ganti rugi dengan pemerintah yang belum terselesaikan, sengketa kepemilikan hak, dimana terdapat beberapa pihak yang mengaku pemegang hak atas tanah tersebut dan adanya wanprestasi dari perjanjian tukar guling lahan. Pemahaman terkait akar sengketa dan faktor pencetus yang membantu untuk merumuskan solusi dari sengketa itu sendiri. Pemahaman yang berbeda terhadap akar sengketa justru membuat sengketa awal menjadi lebih luas, mengingat konflik/sengketa terjadi dikarenakan terdapat pola hubungan superordinasi dan subordinasi dalam wilayah kepentingan negara dan kepentingan perseorangan. ${ }^{35}$

Meskipun diberikannya ganti kerugian yang dilakukan pemerintah kepada yang memegang hak atas tanah yang digunakan untuk kepentingan publik adalah mutlak didapatkan,36 namun dalam hal sengketa tanah di mana bangunan sekolah berdiri tidak

\footnotetext{
${ }^{35}$ Dahrendorf, dalam George Ritzer-Douglas J. Goodman. (2007). Teori Sosiologi Modern. Alih bahasa oleh Alimandan. Jakarta: Kencana, h. 155.

${ }^{36}$ Hamdi, Op., Cit., h. 95.
} 
boleh pemegang hak melakukan main hakim sendiri dengan melakukan penyegelan. Di mana tindakan tersebut merenggut hak mendapatkan pendidikan yang layak khususnya dalam pendidikan formal. Menurut Thomas Jefferson, untuk merumuskan batas bagi hak adalah usaha yang penuh resiko. Ada bahaya, bahwa sesuatu yang sangat hakiki akan terlupakan, hal-hal yang betapa pun diinginkan namun sesekali bukanlah hak akan tercakup di dalamnya. ${ }^{37}$ Oleh karena itu tidaklah mudah untuk mengganti kerugian tanah sekolah dalam waktu singkat, mengingat sekolah yang berdiri tanpa alas hak tersebut berdiri puluhan tahun.

\subsection{Perspektif Hukum Progresif}

Peristiwa penyegelan sekolah oleh pihak yang mengklaim memiliki lahan yang di atasnya berdiri sebuah sekolah merupakan bentuk kegagalan pemerintah dalam melaksanakan tertib hokum hingga administrasi dalam bidang agraria. Argumentasi tersebut juga menandakan bahwa otoritas yang berwenang belum berhasil ataupun gagal melaksanakan diseminasi pengetahuan hukum terhadap masyarakat luas. Argumentasi yang digunakan ialah pengurusan hak atas tanah tukar guling tersebut sulit, bahkan tidak ada kejelasan bukan merupakan suatu pembenaran untuk melakukan penyegelan sekolah yang notabene akan merenggut hak untuk memperoleh pendidikan. Sengketa lahan sekolah memiliki dua ranah yang bersilangan dalam kasus tersebut, yakni ranah administratif dan privat terkait kepemilikan lahan dan ranah publik yakni keharusan untuk memperoleh pendidikan tanpa ada diintervensi oleh masalah apapun. Tindakan penyegelan tersebut dan banyak kasus serupa tersebut dapat dikaji dari segi psikologi dan pendidikan di mana budaya tersebut dalam tingkatan masyarakat rata-rata dapat mempengaruhi sikap tendensi mereka, sekalipun tidak dapat menggeneralisir terhadap semua perilaku yang berkaitan dengan itu. ${ }^{38}$

Budaya dalam paparan di atas dapat dimaksudkan pada budaya hukum yang berkembang di suatu negara sebagai salah satu bentuk penegakan hukum dalam optik kemasyarakatan. Sebagaimana menurut Roscoe Pound yang mengidentifikasi sistem hukum terdapat 3 elemen utama yakni struktur, substansi, dan kultur. Kultur merupakan suatu elemen yang tidak dapat dilepaskan dalam suatu sistem hukum dalam negara. Tindakan penyegelan sekolah oleh pihak yang sebenarnya menuntut hak nya secara pribadi merupakan gabungan banyak faktor yang menjadikan suatu konflik yang berujung pada potensi terenggutnya hak atas pendidikan dasar yang seharusnya diperoleh oleh para siswa. Tindakan main segel sekolah sementara penyelesaian secara yuridis belum selesai atau belum mendapatkan tanggapan oleh pihak yang terkait jika dilakukan pembiaran akan dapat disamakan sebagai tindakan main hakim sendiri atau eigenrichtig. Main hakim sendiri seharusnya tidak hanya dipahami dalam ranah pidana saja, melainkan sebagai bahan untuk dapat memberikan tekanan pada stakeholders. Hal ini bertujuan agar stakeholders segera memberikan apa yang sebenarnya memang merupakan haknya. Kondisi dilematis terjadi di mana terdapat kondisi dalam hal individu yang terenggut karena korban warisan sistem yang sudah berlangsung lama, namun di sisi lain ada kepentingan asasi lain yakni kebutuhan akan pendidikan sebagai suatu hal yang asasi dan harus ada tanpa dikurangi sedikitpun.

37 Effendi, Masyhur. (2012). Memahami Hukum dari Konstruksi Sampai Implementasi: Membangun Kesadaran HAM dalam Masyarakat Modern. Jakarta: Raja Grafindo Persada, h. 83.

${ }^{38}$ Almqvist, J. (2005). Human Rights, Culture and Rule of Law. Oregon: Hart Publishing, p. 41 
Indonesia sebagai negara hukum sebagaimana termaktub dalam Pasal 1 ayat (3) UUD NRI 1945 seharusnya tidak bernegara hukum dalam konteks normatif dan ciri dari pemerintahannya saja, namun harus lebih komprehensif dengan melihat makna dan fungsional pelaksanaan bentuk negara hukum atau rechtstaat itu seperti apa. Baik Ten Berge maupun Van Wijk yang mengemukakan prinsip utama dalam konsep negara hukum ialah dihormatinya hak-hak asasi yang sangat fundamental atau non derogable rights oleh pemerintah itu sendiri. ${ }^{39}$ Terkait dengan hak mendapatkan pendidikan, di negara seperti Swedia, Rusia, Amerika Serikat dan beberapa negara latin bahkan negara di wilayah Amerika Latin sejak tahun 1990an telah mulai menerapkan konsep pendidikan sebagai Jus Commune atau salah satu hak yang harus diperjuangkan secara bersama oleh masyarakat dalam ranah internasional. ${ }^{40}$ Dengan demikian sebenarnya konsep suatu pendidikan sebagai hak dasar yang harus dipenuhi maka pemerintah yang mempunyai kekuasaan dan wewenangnya harus melakukan segala tindakan yang dianggap perlu guna menjamin terselenggaranya pendidikan dasar tanpa ada gangguan apapun.

Problematika tersebut menimbulkan dilematik yang sangat dalam dan tidak mudah untuk diputuskan tanpa menengok faktor apa saja yang menimbulkan terjadinya suatu tindakan semacam itu. Jika disandarkan dalam ranah konstitusi tentu saja melihat dalam Pasal 28 J UUD NRI 1945 yakni setiap kebebasan yang dinikmati oleh warga negara akan dibatasi oleh pembatasan yang dibatasi oleh orang lain. Pengaturan konstitusional semacam ini diperlukan memang untuk mencegah seseorang dalam melaksanakan atau memintakan hak asasinya justru akan melanggar hak asasi orang lain, utamanya jika pelanggaran seperti itu berdampak luas sebagaimana kasus penyegelan tersebut.

Pemikiran hukum progresif sangat mumpuni jika digunakan untuk melakukan konstruksi penyelesaian pada kasus ini. Tipologi hukum progresif yang mencanangkan berhukum dengan hati nurani (conscience) tersebut sangat sejalan dengan negara hukum Indonesia yang berdasarkan atas pancasila ini. Selain itu hukum progresif juga bergerak dalam 2 ranah, yakni ranah sistem dan manusia di mana dalam kedua ranah tersebut memang harus disatukan untuk dapat mencapai hasil yang terbaik sesuai dengan prinsip keadilan substantif yang mengena hingga sasaran yang dituju, yakni keadilan sosial bagi tiap-tiap warga negara itu sendiri. Hukum progresif menjadi memiliki urgensi yang kuat untuk mampu mendobrak aturan hukum yang sangat kaku menjadi lebih manusiawi baik dalam penyusunan terlebih pelaksanaan. Cara tersebut bermanfaat guna mewujudkan hukum yang dapat mencapai tujuan tertinggi dari cita manusia di dunia yaitu kebahagiaan.

Hukum dipergunakan untuk tujuan yakni mencapai harapan-harapan tersebut dan sudah seharusnya bisa memberikan kebahagiaan kepada rakyat dan bangsanya. ${ }^{41}$ Kondisi yang timbul yakni kecurigaan pada aturan hukum dan manusia yang memiliki wewenang atas hukum tersebut muncul berdasarkan diberlakukannya hukum modern dan post-modern yang serba mengandalkan rasionalisasi, formalisasi, dan birokrasi

\footnotetext{
39 Qamar. Op. Cit., h. 17.

40 Schutter, OD. (2010). International Human Rights Law: Cases, Material Commentary. Cambridge:

Cambridge University Press, p. 31.

${ }^{41}$ Rahardjo, Satjipto. (2006). Membedah Hukum Progresif. Jakarta: Penerbit Kompas, h. 10.
} 
hukum di mana hal tersebut merupakan bagian yang negatif dari hukum yang tertulis. ${ }^{42}$ Di sinilah timbul dan perlunya peranan tidak hanya pemerintah dalam mewujudkan perlindungan secara hukum terhadap kontinuitas hak memperoleh pendidikan tersebut, yakni legislatif dan yudikatif juga harus berperan yang sama untuk itu.

Adanya frasa "terutama pemerintah" dalam perlindungan hingga pemenuhan HAM sebagaimana Pasal 28I ayat (4) UUD NRI 1945, mengharusnya adanya pemahaman bahwa pemenuhan hak atas pendidikan harus ditandai dari pemerintah menyadari peranannya sebagai personifikasi negara yang bersifat aktif, bukan pasif dalam pemenuhan hak atas pendidikan tersebut. ${ }^{43}$ Oleh karenanya pemerintah harus bersikap proaktif dengan tidak hanya melakukan penyelesaian terhadap status tanah yang berdiri di atasnya sekolah yang digunakan untuk aktivitas belajar mengajar untuk melakukan penunaian hak asasi ataupun hak konstitusional yakni hak untuk mendapatkan pendidikan, namun juga merancang suatu mekanisme jika terjadi sengketa yang melibatkan kepentingan publik yang besar semacam ini agar tidak terjadi lagi aksi penyegelan yang berimbas pada terenggutnya hak pendidikan siswa dan ketidakpastian status sekolah yang sewaktu-waktu dapat dilakukan penyegelan kembali. Tindakan preventif perlu dilakukan semisal melakukan pendataan terhadap semua sekolah berdiri di atas tanah aset negara atau bukan dan potensi sengketanya di mana harus dapat dipetakan terlebih dahulu sebelum terjadinya hal-hal semacam ini.

Hukum progresif yang menggunakan optik sosiologis yang kuat melihat hukum harus memiliki manfaat sosialnya untuk dapat disebut sebagai hukum. Negara yang paling bertanggung jawab terhadap penyelenggaraan pendidikan sebenarnya memiliki kekhususan sifat yakni memaksa, memonopoli dan mencakup semua yang berhak mengatur memaksakan suatu bentuk produk perundang-undangan atas nama masyarakat. Dengan demikian pemerintah yang harus melaksanakan andil besar dalam tindakan preventif untuk mencegah hal penyegelan yang berpotensi merenggut hak pendidikan siswa itu terjadi, dan melakukan tindakan represif bilamana ada pihakpihak yang memaksakan kehendaknya dengan merugikan kepentingan umum yang lebih luas. Perlu mencapai win-win solution dari pemerintah dan pemilik lahan untuk dapat mencapai konsensus yang tidak merugikan penyelenggaraan pendidikan itu sendiri.

Nurani yang digelorakan hukum progresif harus menjadi pijakan dalam kebijakan yang diambil pemerintah dalam mengatasi problematika seperti ini. Tidak hanya menyelesaikan sengketanya saja, namun pemerintah berkewajiban untuk menunjukkan atau memberikan contoh bahwa dalam penyelesaian sengketa yang bersentuhan langsung dengan hak konstitusional yang lebih besar maka masyarakat haruslah memikirkan kemanfaatan yang terbesar yang akan diperoleh dari sebuah tindakan yang dilakukan tersebut sembari pemerintah harus proaktif dan mencarikan solusi terbaik. Sebagaimana ungkapan dari Jeremy Bentham yaitu "the greatest happiness for the greatest number" itu perlu disosialisasikan terhadap masyarakat luas sebagai salah satu langkah preventif dalam menjamin terselenggaranya pendidikan yang tenang dan tanpa gangguan agar tercapai tujuan pendidikan itu sendiri.

42 Amsari, Feri. (2009). Satjipto Rahardjo dalam Jagat Ketertiban Hukum Progresif. Jurnal Konstitusi, 6(2), h. 180.

${ }^{43}$ Affandi, Hernadi. (2017), Tanggung Jawab Negara dalam Pemenuhan Hak Atas Pendidikan Menurut Undang-Undang Dasar Tahun 1945, Jurnal Hukum Positum Vol. 1 No. 2 Tahun 2017, h. 229. 


\section{Kesimpulan}

Pendidikan adalah hak fundamental yang wajib diterima setiap warga negara sebagai bagian dari berlakunya suatu konsep negara hukum yang meletakkan hak asasi manusia sebagai sesuatu yang tinggi dalam konstitusinya. Sebagai negara yang memiliki tujuan negara mencerdaskan kehidupan bangsa dan segala instrumen yang menjadikan hak memperoleh pendidikan sebagai hak konstitusional, maka hak tersebut perlu dilindungi oleh negara secara penuh agar tidak ada gangguan yang menyebabkan terenggutnya hak tersebut. dalam konteks penyegelan sekolah oleh pihak tertentu maka hukum progresif dengan konsep berhukum dengan nuraninya harus digelorakan untuk dapat menghasilkan penyelesaian yang komprehensif dan total agar tidak lagi terjadi hal serupa di masa mendatang. Sistem dan manusia sebagai ranah gerakan hukum progresif harus diimplementasikan agar problematika semacam ini tidak terjadi, yakni melakukan pendataan ulang terhadap status tanah yang berdiri fasilitas prasarana pendidikan di atasnya, dan kemudian melakukan sosialisasi pada masyarakat berkenaan dengan besarnya kerugian konstitusional terenggutnya hak pendidikan manakala terjadi tindakan semena-mena dengan melakukan penyegelan terhadap prasarana pendidikan tersebut.

\section{Ucapan terima Kasih (Acknowledgments)}

Ucapan terima kasih Penulis tujukan terutama kepada Yulita Dwi Pratiwi, S.H. yang telah membantu dalam meninjau penulisan ini.

\section{Daftar Pustaka}

Buku

Almqvist, J. (2005). Human Rights, Culture and Rule of Law. Oregon: Hart Publishing.

Effendi, Masyhur. (2012). Memahami Hukum dari Konstruksi Sampai Implementasi: Membangun Kesadaran HAM dalam Masyarakat Modern. Jakarta: Raja Grafindo Persada.

Hartono, S. R. (2009). Hak Asasi Manusia: Dalam Perspektif Hukum Perdata Sepanjang Masa. Bandung: Refika Aditama.

Bagir, M. (2001). Perkembangan Pemikiran dan pengaturan Hak Asasi Manusia di Indonesia. Bandung: Alumni.

Marzuki, P. M. (2005). Penelitian Hukum (Edisi Revisi). Jakarta: Kencana.

Murad, R. (1991). Penyelesaian Sengketa Hukum Atas Tanah. Bandung: Alumni.

Qamar, N. (2013). Hak Asasi Manusia dalam Negara Hukum Demokrasi. Jakarta: Sinar Grafika.

Rahardjo, S. (2006). Membedah Hukum Progresif. Jakarta: Penerbit Kompas.

Rahardjo, S. (2009). Hukum Progresif Sebuah Sintesa Hukum Indonesia. Malang: Genta Publishing.

Santoso, U. (2011). Pendaftaran Tanah dan Peralihan Hak Atas Tanah. Jakarta: Kencana.

Santoso, U. (2012). Hukum Agraria Kajian Komprehensif. Jakarta: Kencana.

De Schutter, O. (2010). International Human Rights Law: Cases, Material Commentary. Cambridge: Cambridge University Press.

Susanti, D.O., \& Efendi, A. (2014). Penelitian Hukum: Legal Research. Jakarta: Sinar Grafika.

Jurnal

Affandi, H. (2017). Tanggung Jawab Negara Dalam Pemenuhan Hak Atas Pendidikan Menurut Undang-Undang Dasar Tahun 1945. Jurnal Hukum Positum, 1(2), 218-243. 
Ahmad, I. (2010). Prinsip Keadilan dalam Penyelesaian Sengketa Tanah untuk Kepentingan Pembangunan. Jurnal Legalitas, 3(2), 15-25.

Amsari, Feri. (2009). Satjipto Rahardjo dalam Jagat Ketertiban Hukum Progresif. Jurnal Konstitusi, 6(2), 165-185.

Hamdi. (2014). Penyelesaian Sengketa Penetapan Ganti Rugi dalam Pengadaan Tanah untuk Pembangunan Kepentingan Umum (Kajian Terhadap Undang-Undang Nomor 2 Tahun 2012). Jurnal IUS Kajian Hukum dan Keadilan 2(4), 78-104. http://dx.doi.org/10.12345/ius.v2i4.159

Istanti \& Khisni, A. (2017). Akibat Hukum Dari Akta Jual Beli Tanah di Hadapan PPAT yang dibuat Tidak Sesuai dengan Prosedur Pembuatan Akta PPAT. Jurnal Akta, 4(2), 271-282. http:// dx.doi.org/10.30659/akta.4.2.271\%20-\%20282

Putri, G. F., \& Ana Silviana, S (2016). Penyelesaian Sengketa Tukar Menukar Tanah dalam Pembangunan Prasarana Pendidikan: Studi Kasus di SDN 03 Pakintelan, Gunungpati, Semarang. Diponegoro Law Journal, 5(3), 1-15.

Sujatmoko, E. (2010). Hak warga negara dalam memperoleh pendidikan. Jurnal Konstitusi, 7(1), 181-212.

\section{Peraturan Perundang-Undangan}

Undang-Undang Dasar Negara Republik Indonesia Tahun 1945.

Ketetapan MPR RI Nomor II/MPR/1998 tentang Garis-Garis Besar Haluan Negara

Undang-Undang Nomor 5 tahun 1960 tentang Peraturan Dasar Pokok-Pokok Agraria, Lembaran Negara Republik Indonesia Nomor 104, Tambahan Lembaran Negara Republik Indonesia Nomor 2043.

Undang-Undang Nomor 20 Tahun 1961 tentang Pencabutan Hak-hak Atas Tanan dan Benda-benda yang Ada di Atasnya, Lembaran Negara Republik Indonesia Nomor 288, Tambahan Lembaran Negara Republik Indonesia Nomor 2324.

Undang-Undang No. 39 Tahun 1999 tentang Hak Asasi Manusia, Lembaran Negara Republik Indonesia Nomor 165, Tambahan Lembaran Negara Republik Indonesia Nomor 3886.

Undang-Undang No. 20 Tahun 2003 tentang Sistem Pendidikan Nasional, Lembaran Negara Republik Indonesia Nomor 78, Tambahan Lembaran Negara Republik Indonesia Nomor 4301.

Undang-Undang No. 2 Tahun 2012 tentang Pengadaan Tanah Bagi Pembangunan untuk Kepentingan Umum, Lembaran Negara Republik Indonesia Nomor 22, Tambahan Lembaran Negara Republik Indonesia Nomor 5280.

Peraturan Pemerintah Nomor 19 Tahun 2005 tentang Standar Nasional Pendidikan, Lembaran Negara Republik Indonesia Nomor 41, Tambahan Lembaran Negara Republik Indonesia Nomor 4496

Peraturan Menteri Pendidikan Nasional Nomor 24 Tahun 2007 tentang Standar Sarana dan Prasarana untuk Sekolah Dasar /Madrasah Ibtidaiyah (SD/MI), Sekolah Menengah Pertama/Madrasah Tsanawiyah (SMP/MTs) dan Sekolah Menengah Atas/Madrasar Aliyah (SMA/MA).

Peraturan Presiden No. 71 Tahun 2012 tentang Pengadaan Tanah Bagi Pelaksanaan Pembangunan untuk Kepentingan Umum, Lembaran Negara Republik Indonesia Nomor 156.

Peraturan Menteri Negara Agraria/Kepala Badan Pertanahan Nasional Nomor 1 Tahun 1999 tentang Tata Cara Penanganan Sengketa Pertanahan. 
Makalah

Kementerian Pendidikan dan Kebudayaan. (2018). Media Komunikasi dan Inspirasi Jendela Pendidikan dan Kebudayaan: 279 Triliun Pembiayan Pendidikan Ditransfer ke Daerah. Edisi XXVI/Agustus 2018, Diakses pada https://jendela.kemdikbud.go.id/assets/public/EDISI_26_2018.pdf

Kementerian PPN/Bappenas. (2013). Kebijakan Pengelolaan Pertanahan Nasional. White Paper.

Pahlevi. (2014). Analisis Bentuk-Bentuk Sengketa Hukum atas Tanah Menurut Peraturan Perundang-undangan di Bidang Agraria. Majalah Hukum Forum Akademika.

Website

Budi Widayat. (2018). Lahan Sekolah Masih Sengketa, Ratusan Siswa di Mojokerto Mengungsi. Meredeka.com. diakses pada https://www.merdeka.com/peristiwa/lahan-sekolah-masih-sengketa-ratusansiswa-sd-di-mojokerto-ngungsi.html

Ellya. (2017). Penyelesaian Sengketa SD Karangasem Tempuh Jalur Hukum. Berita Jateng.net. diakses pada http://beritajateng.net/penyelesaian-sengketa-tanahsd-karangasem-tempuh-jalur-hukum/

Radar Madura.id. (2018). Siswa SDN Madulang 2 Belajar di Tempat Parkir Motor. Diakses pada

https://radarmadura.jawapos.com/read/2018/03/28/60556/siswa-sdnmadulang-2-belajar-di-tempat-parkir-motor

Koran Kaltara. (2017). Bupati Pastikan Segera Tuntaskan Lahan Sekolah. Diakses pada http://www.korankaltara.co/read/news/2017/29181/bupati-pastikan-segeratuntaskan-sengketa-lahan-sekolah.html

KPAI. (2018). Pers Release Ekspose Pengawasan KPAI Bidang Pendidikan April-Juli 2018 Trauma. Diakses pada http://www.kpai.go.id/berita/pers-releaseekspose-pengawasan-kpai-bidang-pendidikan-april-juli-2018-trauma-beratcedera-fisik-sampai-kematian-akibat-kekerasan-di-sekolah

Rahardlan, Ar. (2017). Tingginya Angka Putus Sekolah di Indonesia. Diakses pada https://student.cnnindonesia.com/edukasi/20170417145047-445208082/tingginya-angka-putus-sekolah-di-indonesia/

Darwiaty Dalle. (2017). DPRD Minta Pemerintah Daerah Tuntaskan Sengketa Lahan Sekolah. Sindonews.com. Diakses pada https://makassar.sindonews.com/read/76/1/dprd-minta-pemerintah-daerahtuntaskan-sengketa-lahan-sekolah-1508256644

Nanang Fahrurozi. (2019). Tanah Sekolah Disegel Ratusan Siswa Tak Bisa Sekolah. Sindonews.com. Diakses pada https://daerah.sindonews.com/read/1372427/174/tanah-sekolah-disegelratusan-siswa-tak-bisa-sekolah-1548092523

Tempo.co. (2010). Sengketa Lahan Sekolah Jadi Momok Bagi Dunia Pendidikan. Diakses pada https://nasional.tempo.co/read/249952/sengketa-lahan-sekolah-jadimomok-bagi-dunia-pendidikan

Zamachsari. (2018). Sengketa, Gedung SD di Sampang Disegel Warga. Diakses pada http://beritajatim.com/hukum_kriminal/324459/sengketa,_gedung_sd_di_sa mpang_disegel_warga.html/ 